\title{
Using comprehension questions and reader-response strategies with second-semester university Spanish students
}

\author{
Brian Hibbs \\ Dalton State College \\ (Text received 22 February 2017; accepted 09 October 2017; final version 29 November 2017) \\ DOI: https://doi.org/10.5565/rev/jt13.706
}

\begin{abstract}
For most of the $20^{\text {th }}$ century, literary criticism has focused on uncovering the author's intended meanings of a given text. In contrast, reader-response theorists have concentrated on the role of the reader in literary interpretation. This article details an exploratory study which documents second-semester university Spanish students' perceptions of their experiences reading children's novels in Spanish. Learners participated in curricular engagements designed to facilitate their understanding and promote the development of their own interpretations of the books. Results of the study suggest that such engagements may either contribute or impede students' comprehension and interpretation of literary texts due to various contextual factors.
\end{abstract}

Key Words: literature, comprehension, reader-response, children's literature, interpretation

Resumen: Durante la mayoría del siglo XX, la crítica literaria ha enfocado en el descubrimiento del significado de un texto literario según el autor. Sin embargo, académicos en el campo de la teoría de la recepción han concentrado en la función del lector en la interpretación literaria. Este artículo describe una investigación exploratoria que intenta averiguar las perspectivas de estudiantes universitarios estadounidenses que leían novelas infantiles en español en clase al nivel elemental. Los estudiantes participaron en actividades para facilitar su comprensión y desarrollar sus propias interpretaciones de los libros. Los resultados del estudio demuestran que dichas actividades pueden contribuir o impedir su comprensión e interpretación de textos literarios debido a varios factores contextuales.

Palabras claves: literatura, comprensión, teoría de la recepción, literatura infantil, interpretación

Résumé: Pendant la majorité du XX siècle, la critique littérarite concentrait sur le sens d'un texte littéraire selon l'auteur. Néanmoins, les academiciens de la théorie de la réception focalisent leurs efforts sur le rôle du lecteur dans l'interprétation littéraire. Cet article décrit une étude exploratoire qui envisageait recollecter les perspectives d'étudiants universitaires étatsuniens qui lisaient romans pour enfants en espagnol dans leur cours au niveau élémentaire. Les étudiants ont participé dans plusieurs activités pour faciliter leur compréhension y développer leurs propres interprétation des livres. Les résultats de l'étude démontre que ces activités peuvent contribuer o contraindre leur 
compréhension et interprétation de textes littéraires à cause de plusieurs facteurs contextuels.

Mots clés: littérature, compréhension, téorie de la réception, romans pour enfants, interprétation

\section{Introduction}

In the early $20^{\text {th }}$ century, critics frequently considered the life and times of the author when interpreting literary texts by perceiving texts as socio-historical documents possessing one "correct" interpretation: that of the author. The New Critics subsequently changed the direction of literary criticism by perceiving the text as an autonomous entity free from the writer's control and authority and by viewing literary texts as self-contained units independent of authorial and sociocultural contexts. They argued that "the meaning of the text is never self-formulated; the reader must act upon the textual material in order to produce meaning" (Selden \& Widdowson, 1993, p. 49). Reader response theorists explore readers' experiences with literary texts, while reception theorists examine ways in which readers make meaning from literary texts. Although these scholars have approached the role of the reader in different ways, their shared interest lies in the exploration of the dynamic relationship between readers and texts (Kern, 2000).

Although the interaction between reader and text has been conceptualized in a variety of ways, this research study drew principally on the scholarly work of Louise Rosenblatt and her transactional theory of reading. Rosenblatt views the reading process as a triadic cycle between the reader, the text and the "poem" or a new text created by the fusion of the text and the reader's experiences with the text. Her transactional theory of reading examines the active role of the reader in making meaning.

Rosenblatt (1994) defines a text as a "set or series of signs interpretable as linguistic symbols" (p. 12). In her view, a given text provides a range of "potentialities" (p. 69) to activate readers' knowledge and previous experiences which readers subsequently use to make sense of the text. As the reader works to make meaning of the text, s/he "lives through" the text and "build[s] up the work under the guidance of the text" (p. 69) by establishing connections between his/her previous knowledge and life experiences and the story world of the text. The reader then 
reflects on this process of blending the text with his/her life experiences. Rosenblatt explains that meaning does not reside entirely in the text or entirely in the reader but is "built up through the back-and-forth relationship between reader and text" (Karolides, 1999, p. 160). She argues that "the literary experience reside[s] in the synthesis of what the reader already knows and feels and desires with what the literary text offers" (Rosenblatt, 1995, p. 259) and that what the student brings to the literary experience is as important as the literary text itself.

Rosenblatt defines a transaction as a "two-way process involving a reader and a text at a particular time under particular circumstances" (Rosenblatt, 1982, p. 268). The reader "transacts" with the text by transforming the signs in the text into verbal symbols and fusing them with his/her personal knowledge and the emotions, memories and experiences the text evokes. The outcome of this transaction is a "poem", or a new text derived from the amalgamation of the text, the reader, and the reader's experience with the text. Rosenblatt argues that the reader creates this poem through a combination of the signs of the text, his/her previous life experiences, and the lived-though experience of reading the text.

\section{Literature Review}

Researchers investigating the role of reader response theory in foreign/second language classrooms have explored a variety of response engagements, including response journals, verbal self-reports, post-reading responses and focal practice.

Several studies have considered the use of response journals in language classrooms to help learners develop their own understandings of literary texts. Liaw (2001), for example, examined the use of response journals with ESL students in a Taiwanese university. As part of a freshman English course, students read short stories in English and wrote journal entries summarizing the stories and describing their personal responses to the stories. Students indicated that reading the stories helped them learn more about American society and culture, become more reflective and conscious of themselves and the world around them, and develop a strong sense of confidence in their reading abilities.

A number of studies have also explored using reader-response engagements with language students to promote their personal interpretations of texts. For example, Chi (1999) utilized such engagements with her Taiwanese EFL learners by asking them to read two short 
stories and subsequently complete verbal self-reports and free oral post-reading responses to the stories. In their verbal-self reports, students read each short story and reported what they were thinking and feeling as they read the story. Students then read the story a second time and indicated how their previous understandings and interpretations had changed because of the second reading. Chi's analysis revealed that students tended to (not) exhibit what the author termed "flexibility", or "the forming and re-forming-of the participants' framework of sensemaking through continual finding, building, and making sense of the texts" (p. 7). Those students exhibiting behaviors of flexible readers were actively involved in the process of comprehending and interpreting the stories. They trusted themselves in the meaning-making process by engaging in dialogic communication with the author and readjusting their understandings of the stories. Students demonstrating behaviors of inflexible readers, on the other hand, often felt it was primarily the author's responsibility to make texts easier to understand. They tended not to include themselves in the story worlds of the texts and exhibited difficulties making connections between the stories and their own lives.

Additionally, González (2006) incorporated a focal practice approach in a third-year university Spanish course through the reading of a novel by Sandra Cisneros. The focal practice approach is designed to encourage students to develop their own responses to a text, share their personal responses of the text with others, and re-read the text to see if their initial responses to the text had changed. González recorded students' responses to the text, conducted participant observations and a focus-group interview, and analyzed documents produced by him (observation field notes, reflective journal) and his students (final presentations). González found that the focal practice approach supported learners in accepting responsibility for their own learning, being motivated to read, and finding pleasure in reading.

These studies make important contributions to our current understanding of the role of reader-response theory in language classrooms. Liaw (2001) demonstrates that completing reading logs can help students dig deeper into texts and make connections between the texts and themselves. Chi (1999) and González (2006) show that reader-response engagements can help students develop their own interpretations to literary texts. Both studies indicate that students process texts more deeply if they make efforts to extract their own meanings from these texts, 
engage in dialogic inquiry with the author, are willing to adjust their perceptions of texts as they read, and make connections between the texts and their own lives.

Despite their valuable contributions, however, these students possess several limitations. Although Liaw (2001) explores the use of response journals, she does not include readerresponse engagements as part of the course curriculum. Although Chi (1999) does use response engagements with students, these engagements are used in a quasi-experimental setting and are not utilized in an actual classroom context. Moreover, the participants in these studies were advanced ESL students. Additionally, despite the fact that González (2006) does include readerresponse engagements as a part of the Spanish course curriculum, the students in this study were advanced level learners only. The current study aimed to fill these gaps by using reader-response engagements with elementary-level students.

\section{Research Context}

This study was conducted with three sections of a second-semester Spanish course at a large university in the Southwestern United States: two sections during the fall semester of 2008 (Classes \#1 and \#2), and one section during the spring semester of 2009 (Class \#3). Because I was attempting to investigate the implementation of a new curricular approach to teaching Spanish, and because my students were informants helping me understand the complexities of this new curricular approach, the students who participated in the study were those enrolled in sections for which I was the instructor. The Spanish course was taught using a communicative framework focused on developing students' communicative competencies in Spanish, their acquisition of vocabulary words and specific grammatical features of Spanish, and their knowledge of various facets of the history and cultures of various countries in the Spanishspeaking world.

Students also read two children's novels as part of the course curriculum: Me llamo María Isabel [My Name Is María Isabel] and Béisbol en abril y otros cuentos [Baseball in April and Other Stories]. Students in Classes \#1 and \#2 read Me llamo María Isabel in its entirety and two short stories from Béisbol en abril y otros cuentos. Due to time and curricular constraints, students in Class \#3 only read five chapters from Me llamo María Isabel and did not read Béisbol en abril y otros cuentos. Each section met four days per week for sixteen weeks; one class 
session each week was dedicated to reading and discussing the children's novels. During these weekly sessions, students read a chapter or short story from each book in groups and either answered comprehension questions concerning the text (Classes \#1 and \#2) or participated in response engagements designed to elicit their initial interpretations of the text (Class \#3). Students then took part in class discussions in Spanish to deepen their understanding of the text and explore aspects of Latino culture contained in the text.

The first book (Ada, 1993) describes the life María Isabel Sálazar López, a nine-year-old girl who emigrates from Puerto Rico to the United States with her family. On the first day at her new school, the teacher changes María's name to Mary since there are already two girls named María in the class. The book traces the main character's process of finding her place in a new land while also maintaining her cultural identity and heritage.

The second book (Soto, 1990) is a collection of eleven short stories in which the characters are adolescent Latinos from California. The stories use small events of daily life to elucidate themes common to all adolescents. Students in Classes \#1 and \#2 read two stories in the collection, 'Béisbol en abril' and 'El Karate Kid'. The first story explores two brothers' experiences playing for a local baseball team; neither they nor the team play well. Towards the end of the season, the team plays and loses against a much better team. After their defeat, the boys lose interest in playing baseball, and one brother quits the team to date his new girlfriend. In the second story, a boy is frequently bullied at school because of his small size. Inspired by the film The Karate Kid, the boy decides to enroll in a karate class to learn how to defend himself. He soon finds out, however, that the class is much more difficult than he had anticipated. Gilbert soon tires of the karate class and eventually stops attending the class altogether. He decides instead to read comic books since comics are not nearly as painful as karate.

Seventy-eight students were enrolled in three sections of a second-semester university Spanish course for which I was the instructor; sixty-eight students consented to participate in the study. $89.2 \%$ of students were between 17 and 21 years of age. $52.6 \%$ of students were male, and $47.4 \%$ of students were female. $69.2 \%$ of students identified themselves as Caucasian or White. 


\section{Data Collection and Analysis}

Four data sources were included in the study: journal entries, surveys, focus-group interviews and a composition.

Students in all three sections completed periodic journal entries in which they reflected on their experiences reading the children's novels. Students wrote their entries in English so that they could freely express their perspectives on the children's books without their imperfect knowledge of Spanish preventing them from accurately conveying their perceptions.

Participants in Classes \#1 and \#2 completed two surveys (Surveys \#1 and \#2), and participants in Class \#3 completed one survey (Survey \#1) in English. This first survey asked students to summarize their experiences reading Me llamo María Isabel and note salient features concerning the Spanish language and Latino culture; the survey was administered after students had finished reading the book. The second survey asked students to evaluate their experiences reading the two short stories in Béisbol en abril y otros cuentos and explore linguistic and cultural connections they made with the stories. Survey \#2 was administered in Classes \#1 and \#2 after students finished reading the stories; the survey was not administered to Class \#3 since the class did not read these stories.

Three focus-group interviews were conducted in English during the study, two in Classes $\# 1$ and \#2 and one in Class \#3. Classes \#1 and \#2 were divided into two groups of approximately thirteen students each for logistical considerations to maximize student responses; Class \#3 was not divided into smaller groups since there were fewer students in this section. During the first focus-group interview, students reflected on their experiences reading Me llamo María Isabel. During the second focus-group interview, students considered their experiences reading the two short stories in Béisbol en abril y otros cuentos. Students in Class \#3 completed one focus-group interview but did not take part in a second interview since they did not read Béisbol en abril $y$ otros cuentos. The focus-group interviews provided students with an opportunity to explain and expand on their responses on each survey respectively. Each interview lasted approximately one hour and was videotaped; significant quotes from the interviews were subsequently transcribed.

Finally, students wrote a composition in Spanish in which they compared and contrasted their feelings concerning their names with those of María Isabel. In the composition, students reflected on María Isabel's feelings about her names and their impressions of their own names. 
Two research frameworks structured the study: teacher research and grounded theory. Teacher research was selected as a framework since I wished to learn more about utilizing children's literature as a curricular approach with my students. Cochran-Smith and Lytle (1990) define teacher research as "systematic, intentional inquiry by teachers" (p. 2). They contend that, by collecting and analyzing data, devising a plan for collecting and analyzing data, and reflecting on and make sense of their experiences, teacher research allows educators to answer meaningful questions about their own teaching and their students' learning. Teacher research thus framed the study in order to help me make sense of my students' experiences reading the children's novels in a systematic and intentional way.

Additionally, grounded theory was incorporated as a second framework in order to better understand and develop an initial theory about the role of children's literature in language and culture acquisition. According to Creswell (2009), grounded theory guides researchers in constructing a theory of a given phenomenon based upon the perspectives of the participants. Grounded theorists collect data concerning a given phenomenon, analyze the data through conceptual categories, develop an initial theory from the conceptual categories, and continue to collect and analyze data until the theory is established (Glesne, 2010). This study utilized grounded theory as a methodological framework by using students' perceptions as a basis for establishing a theory of how elementary-level students in Spanish view reading children's literature in Spanish

This study utilized purposeful sampling in its design by recruiting participants who would provide information-rich data for the study (Patton, 2002). Since teacher research was one framework that shaped the study, and since my goal was to develop a theory concerning the use of children's literature in Spanish with elementary-level students studying Spanish at the college level, I selected participants for the study among students from my own classes.

The study incorporated the constant comparison method (Glaser \& Strauss, 1967) by using themes and categories to build theory. The data for the study were analyzed through open coding by reading the data sources several times and identifying tentative themes emerging from the data. An initial analysis memo was constructed which listed each theme, a working definition of the theme, and several student quotes exemplifying the theme. In order to perform a deeper 
analysis of the data, the themes were then reshuffled, reorganized and grouped into broader categories, which were triangulated amongst the data sources.

\section{Curricular Engagements}

In Classes \#1 and \#2 (the "comprehension" group), the curricular engagements focused on developing students' comprehension of the children's novels. Learners read a given chapter or short story, completed comprehension questions in Spanish about the text, and discussed their answers to the questions. Below is an example of comprehension questions students answered for Chapter 1 of Me llamo María Isabel.

1. Cuando eras niño/a, ¿te gustaba el primer día de clases? ¿Por qué (no)?

[When you were a child, did you like the first day of school? Why (not)?]

2. ¿Está María Isabel contenta este primer día de clases? ¿Por qué (no)?

[Is María Isabel happy on her first day of school? Why (not)?]

3. Cuando María Isabel camina hacia el autobús, ¿qué le pasa?

[When Maria Isabel walsk to the school bus, what happens to her?]

4. ¿Por qué el vestido María Isabel es importante a ella?

[Why is Maria Isabel's dress important to her?]

5. ¿Por qué María Isabel decide llevar el vestido este día?

[Why does María Isabel decide to wear that particular dress that day?]

Figure 1: Comprehension Questions for Chapter 1 of Me llamo María Isabel

In Class \#3 (the “interpretation” group), students participated in curricular engagements designed to help them develop their own interpretations of the children's novel. Instead of answering comprehension questions, students participated in various response engagements as they read a given chapter in Me llamo María Isabel. The class then discussed in Spanish their responses to the engagement and their understandings/interpretations of the chapter. 
Several response engagements were used with students in Class \#3. For example, the Graffiti Board engagement (Short, Harste \& Burke 1996) prompted students to document their initial feelings, impressions and connections through single words, complete sentences and/or pictures. I read aloud the first chapter of Me llamo María Isabel as students completed their Graffiti Boards and subsequently shared them with a partner. This engagement provided students an opportunity to document and consider their initial thoughts and impressions of the text.

Figure 2 below is an example of Kendall's Graffiti Board. The student is beginning to develop initial thoughts and perspectives on the chapter while also verifying his/her (mis)understanding of the chapter.

ifie bouk was ient descriptive of mat she was weding. The mention of bue backpack was very ofien. It ded not sem that her moiner made a big deal abot her fist day at a new senool which Ithought she wolid have. she sums like a brave gin and is kind of anxios me nervous to start Class: Did it say that the kids were not welcoming to her?

Figure 2: Graffiti Board

A second response engagement students participated in was Say Something (Short, Harste \& Burke, 1996). Students read Chapter 3 of Me llamo María Isabel in groups. One student read one page of the chapter aloud while other students in the group followed along. After the student finished reading, the group shared their thoughts, impressions and personal connections and asked questions about parts of the chapter they did not understand. This cycle continued until the 
group finished reading the chapter, after which they stopped to reflect on their impressions of the chapter as a whole. This engagement allowed students to share their thoughts and questions with other group members while also providing them with opportunities to consider their perceptions of the chapter as they were reading.

A third response engagement used with students in Class \#3 was a Written Conversation (Short, Harste \& Burke, 1996). Students individually read Chapter 4 in Me llamo María Isabel. After having read the chapter, students were separated into pairs. Without talking, they exchanged one sheet of paper back and forth between them while engaging in a written conversation about the chapter in which they recorded their thoughts and impressions of the text and/or responded to a question or comment written previously by the other partner. Each pair participated in several cycles of the written conversation. This engagement helped students think more deeply about their views of the chapter while also helping them consider perspectives of the text that may be different from their own. Figure 4 is an example of a written conversation between two students about Chapter 4 in Me llamo María Isabel. Each line of the conversation expands on and/or extends the student's view of the chapter from the previous line. 
- Mul experienee with havia kabel have been ferive. I feel it exposed me to another format of sponish.

- My experience was also positive. I garee wrth-yos--" on the format.

- I didnt like the way the teacker picked on MI I would have hated him and chamged classes.

- I would agree felt the teacher could have been micer to luer. I also felt vad for maria when she fell doun in fiont of exough an the bos and thuy mopich ot hé.

- I think the book she chase to read ont of the librory was an excallent choice. I ve read it and could relate.

- I would agree I read the book she chose when I was yourlace and 1 enjoufed it.

- Agreed

Figure 3: Written Conversation

A fourth and final response engagement students engaged in was Save the Last Word for Me (Short, Harste \& Burke, 1996). After having read a text, students select a quote or short passage from the text that they find significant. One student begins by sharing his/her quote/passage while the other students in the group share their thoughts and impressions about the quote; the first student then explains why s/he selected the quote. The activity is designed to maximize the variety of responses to students' quotes and help them consider multiple perspectives and interpretations of the text.

Class \#3 participated in a variation of Save the Last Word for Me. Students divided themselves into groups and read Chapter 5 of Me llamo María Isabel. Each group selected a phrase or sentence from the chapter that they found important or significant, wrote their group's phrase or sentence on the board, and explained in Spanish why their group selected the sentence. 
Students participated in this engagement in groups and as a class in order to expose them to various possible interpretations of and perspectives on the chapter.

The curricular engagements outlined above were included in the study to support students' comprehension of the children's novels as well as their understanding of various aspects of Latino culture. In Classes \#1 and \#2, the engagements focused on promoting students' understanding of Me llamo Maria Isabel and Béisbol en abril y otros cuentos. In Class \#3, the engagements centered on students' initial comprehension of Me llamo Maria Isabel and the subsequent development of their personal understandings of the book. Students' comments can help us better understand the role of the curricular engagements in accomplishing these goals.

\section{Findings}

Several abbreviations will be used when presenting students' quotes. " $\mathrm{C}$ ' refers to the class the student was enrolled in, "J" refers to journal entries, "S" refers to surveys, "FGI" refers to the focus-group interviews, and "CP" refers to the composition. All students' names are pseudonyms.

Numerous students in Classes \#1 and \#2 believed that the comprehension questions contributed to their understanding of Me llamo Maria Isabel because the questions provided them with the organizational structure of a given chapter, thus helping them focus on what was important and significant in the chapter.

- I think that [the comprehension questions] have been helpful because they outline the chapter we are about to read or give us a focus for the chapter and help keep us on the right track. [Naomi, C\#2, J\#2]

- The [comprehension] questions act as a guide to steer us on the right direction as to what

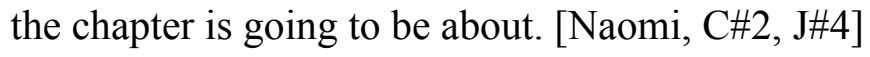

- I think that [comprehension questions] act as guidelines and give hints about what the chapter is about. [Naomi, C\#2, J\#3]

According to these students, the comprehension questions facilitated their comprehension of Me llamo Maria Isabel because the questions developed their awareness of the narrative structure of the chapters they were reading. 
Students also maintained that the structure of the questions provided them with opportunities to compare/contrast their life experiences with those of the characters.

- I think with the [comprehension] questions [we] were able to pick out what they mean because we're comparing the questions to ourselves... [Mackenzie, C\#1, $\mathrm{J} \# 3$ ]

- I really liked how on the worksheets we did, you asked us questions about our lives, which allowed me to better understand the question[s] about the book. [Tim $\mathrm{C} \# 2, \mathrm{~S} \# 2]$

Other students noted that the comprehension questions impeded their comprehension of the children's books because the questions forced them to focus on specific details within a given chapter instead of helping them understand the chapter as a whole.

- The negative experiences I had [reading Me llamo María Isabel] was when you gave us a sheet of questions to answer. I would read for the answers, not to understand the book. [Barry, C\#1, S\#2]

- When we would use the [comprehension questions] I would just look for the answers and that was it, I did not always understand what was going on in [Me llamo María Isabel]. [Barry, C\#1, J\#3]

- When given a worksheet, you tend to focus only on the parts of the chapter that specifically relates to the questions. [Gabriella, C\#2, J\#3]

Students in Class \#3 identified various positive aspects of the reader-response engagements. For example, certain students noted that the Graffiti Boards contributed to their comprehension of the children's novels because they were able to record their evolving understandings of the books.

- I think that the whole Graffiti Board when you were reading to us helped me understand a little more. The purpose of that was to jot down what got out of the readings and record some familiar words to help us understand the book better. That Graffiti Board helped me and is definitely something that you should do with other classes. [Wyatt, C\#3, S\#2]

- I liked that we were jotting down whatever we felt like while we were listening to the book because that gave me a chance to write down things I remembered in the book and

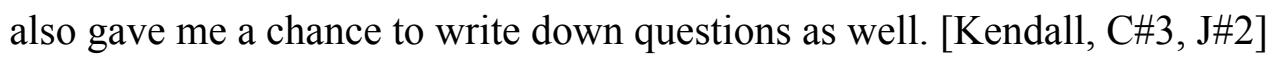


- One thing that I really like about reading Me llamo María Isabel is using the Graffiti Boards as a response. Using these seems like a good way to accurately express immediate reactions to the text. [Savanna, $\mathrm{C \# 3}, \mathrm{J} \# 2$ ]

- I also prefer [the Say Something engagement] over answering [comprehension] questions because we are so worried about answering them that we just look for any words and try to get it [answering the questions] done rather than understand what is going on. [Damon, $\mathrm{C} \# 2, \mathrm{~J} \# 3$ ]

Students also indicated that the Graffiti Boards helped them make personal connections between their life experiences and those of María Isabel.

- Graffiti Board[s] helped me connect my feelings to those María [Isabel] may be experiencing. [Ethan, C\#3, J\#4]

These students indicated that the Graffiti Boards promoted their understanding of the children's novels because this activity allowed them to document their thought process as they read the books while also helping them connect their life experiences to those of the characters.

\section{Discussion}

Results of this study demonstrate that the curricular engagements contributed to students' understanding of the children's novels by helping them visualize the narrative structure of the chapters and short stories they read and affording them space to verify their comprehension and record their understandings of what they were reading. However, students also concluded that, in other respects, the curricular engagements did not facilitate their comprehension of the books since they either focused learners' attention exclusively on specific details of the texts or prevented students from understanding what they were reading. In Classes \#1 and \#2, for example, students indicated that the comprehension questions contributed to their understanding of the books because the questions allowed them to focus on important events in given chapters by signalling the overall organization of the chapters. It is conceivable that students with lower proficiency in Spanish as well as students less familiar with the narrative structure of the novel may have benefitted from the linguistic and structural scaffolding provided by these questions.

Other students, however, noted that the questions hindered their comprehension of the books because, instead of trying to understand each chapter as a whole, they tended to scan the 
chapters for specific information that would help them answer the comprehension questions. Students with higher proficiency in Spanish and/or students who are more familiar with fictional narrative structure may have possibly felt that the questions guided them to one particular perspective and prevented them from forming their own interpretations of the books. In Class \#3, students noted that the reader-response engagements helped them understand the novels by documenting their thinking about the books and sharing their perspectives of the texts while listening to those of their classmates. Students stated that the responses engagements also helped them make connections between the characters' life experiences and their own. Several students did note, however, that they encountered difficulty completing the Graffiti Boards while listening to a read aloud of Chapter 1 of Me llamo Maria Isabel because they were unable to focus simultaneously on what they were hearing and what they subsequently documented on their Graffiti Boards. As with the comprehension questions, students' proficiency level in Spanish may be one possible explanation for this finding.

The curricular engagements also aided students in creating connections between their life experiences and those of the characters. The engagements facilitated students' amalgamation of reader, text and textual experience or "poem" (Rosenblatt, 1994). This supports findings obtained by Liaw (2001) and González (2006) in that the response engagements deepened their transactions with the children's books. Students' reactions to these activities indicate that they were able to create an initial, albeit somewhat superficial, interpretation of the children's books. This may have possibly been due to students' unfamiliarity and lack of experience with these engagements. Additionally, they may have encountered few opportunities to develop their own textual interpretations in previous literature courses.

Students' comments suggest that both types of curricular engagements facilitated their understanding of the books and supported them in making connections between the experiences of the characters and their own lives. This is a somewhat surprising finding, considering that the comprehension questions were structured to help students understand the main points of the children's novels, while the responses engagements were designed to facilitate their interpretations of the books. This finding suggests that, rather than including only comprehension questions or responses engagements exclusively, educators might use both types of engagements to strengthen students' textual comprehension while also assisting them in developing their own 
understanding of texts and establishing linkages between their own life experiences and those of the characters. Literacy education has traditionally presumed that comprehension precedes interpretation in the belief that students need to understand what they are reading before they are able to construct their own interpretations. This finding suggests that interpretation may develop alongside or even precede comprehension. In other words, students may in fact need multiple opportunities to develop their own initial interpretations of a given text before they can understand it.

\section{Conclusion}

Results of the study demonstrate that comprehension questions and response engagements, if designed appropriately, can support students' comprehension of texts while also facilitating the development of their own interpretations of these texts. As noted above, findings suggest that, contrary to traditional criticism, comprehension does not necessarily precede interpretation. Students need time and space to make their personal connections with a text before they are able to understand the main points of the text. Rather than attempting to uncover what a text "means", students need opportunities to first develop their own understandings of a text that subsequently help them comprehend the salient points of the text. Rosenblatt (1982) contends that "the notion that first the child must 'understand' the text...before it can be responded to...is a rationalization that must be rejected" (p. 273). It is my hope that this article will aid and support language educators as they work to provide students with opportunities to develop personal and meaningful relationships with literary texts.

\section{References}

Ada, A. (1993). Me llamo María Isabel. New York: First Aladdin Paperbacks/Libros Colibrí.

Chi, F. (1999). Reading as transaction in EFL: A thematic analysis. ERIC Document Reproduction Services No. ED437855.

Cochran-Smith, M., \& Lytle, S. (1990). Teacher research and research on teaching: The issues that divide. Educational Researcher, 19(2), 2-11. DOI: https://doi.org/10.2307/1176596 Creswell, J. (2009). Research design: Qualitative, quantitative and mixed methods approaches 
(3rd ed.). Thousand Oaks, CA: SAGE Publications, Inc.

Glaser, B., \& Strauss, A. (1967). The discovery of grounded theory: Strategies for qualitative research. Chicago, IL: Aldine Publishing Co.

Glesne, G. (2010). Becoming qualitative researchers: An introduction (4 ${ }^{\text {th }}$ ed.). Boston: Pearson.

González, I. (2006). Reader response as a focal practice in foreign language acquisition. Copyrighted Master's thesis.

Karolides, N. (1999). Theory and practice: An interview with Louise M. Rosenblatt. Language Arts, 77(2), 158-170.

Kern, R. (2000). Literacy and language teaching. Oxford, UK: Oxford University Press.

Liaw, M. (2001). Exploring literary responses in an EFL classroom. Foreign Language Annals, 34(1), 35-45. DOI: https://doi.org/10.1111/j.1944-9720.2001.tb02800.x

Patton, M. (2002). Qualitative evaluation and research methods (3rd ed.). Thousand Oaks, CA: SAGE Publications.

Rosenblatt, L. (1982). The literary transaction: Evocation and response. Theory into Practice, 21(4), 268-277. DOI: https://doi.org/10.1080/00405848209543018

Rosenblatt, L. (1994). The reader, the text, the poem: The transactional theory of the literary work. Carbondale, IL: Southern Illinois University Press.

Rosenblatt, L. (1995). Literature as exploration (5th ed.). New York, NY: Modern Language Association of America.

Selden, R., \& Widdowson, P. (1993). A reader's guide to contemporary literary theory (3rd ed.). Lexington, KY: The University Press of Kentucky.

Short, K., Harste, J., \& Burke, C. (1996). Creating classrooms for authors and inquirers. Portsmouth, NH: Heinemann.

Soto, G. (1990). Béisbol en abril y otros cuentos. Miami, FL: Santillana USA Publishing Co, Inc.

\section{Author Information:}

Brian Hibbs (Ph.D.) is currently assistant professor of education at Dalton State College in Dalton, GA, USA. Under the direction of Dr. Kathy Short, he successfully defended his doctoral dissertation in the Interdisciplinary Ph.D. Program in Second Language Acquisition and Teaching at the University of Arizona in January of 2014. His research interests include second language pedagogy, intercultural competence, and applied linguistics.

Email: bhibbs@daltonstate.edu

Bellaterra Journal of Teaching \& Learning Language \& Literature. 10.4 (Nov-Dec 2017) ISSN 2013-6196 
To cite this article:

Hibbs, B. (2017). Using comprehension questions and reader-response strategies with second-semester university Spanish students. Bellaterra Journal of Teaching \& Learning Language \& Literature, 10(4), 49-67. DOI: https://doi.org/10.5565/rev/jt13.706

(c) (1)

Bellaterra Journal of Teaching \& Learning Language \& Literature. 10.4 (Nov-Dec 2017) 